\title{
Financing Difficulties of SMEs from Its Financing Sources in China
}

\author{
Juanjuan Jiang1, Zhiming Li1, Chanyan Lin² \\ ${ }^{1}$ School of Management, Guangdong University of Technology, Guangzhou, China \\ ${ }^{2}$ School of Management, Jiangnan University, Wuxi, China \\ Email: 983534367@qq.com
}

Received 21 March 2014; revised 18 April 2014; accepted 12 May 2014

Copyright @ 2014 by authors and Scientific Research Publishing Inc.

This work is licensed under the Creative Commons Attribution International License (CC BY).

http://creativecommons.org/licenses/by/4.0/

(c) (i) Open Access

\begin{abstract}
With the rapid development of global economy, the reform and opening up policy of China has provided good opportunities for the vigorous development of small and medium-sized enterprises (SMEs). And SMEs have become the important force of sustained, rapid and healthy development of China's economy. Moreover, SMEs have played an irreplaceable role in promoting China's economic development, absorbing labors and promoting market prosperity. But with the global economic integration, the domestic small and medium-sized enterprise's operating environment is facing tremendous changes and more intense competition. This paper introduces the sources of SMEs' financing, analyzes its financing difficulties and causes from its sources, and aims to benefit the development of SMEs in the near future.
\end{abstract}

\section{Keywords}

Financing, SME, Causes

\section{Introduction}

So far, there are more than 43,000,000 small and medium-sized enterprises, playing an important role in the economy of China. Yet, they still face many difficulties to achieve further development, especially in financing [1]. This paper mainly analyzes its financing difficulties from the aspect of financing channels, and mastering applicability and feasibility of financing channels is of great significance to the development of SMEs, and even the economy in China.

\section{The Sources of Financing SMEs}

Financing is one of the methods for enterprises to get capital [2]. According to different standards, financing can 
be divide into many kinds, this paper divides financing according to its sources into two kinds, namely, internal and external financing.

\subsection{Internal Financing}

Internal financing in fact means enterprises get capital from their own, mainly including retained profits and depreciation, which is an essential part for the survival and development of the enterprises. Generally speaking, internal financing is the first choice, an important source to get capital.

\subsubsection{Retained Profits Financing}

Retained profits is an important channel of internal financing, and most enterprises prefer to choose this, as it is actually an process that transform retained profits into investment, this method shows some advantages as follows: first, no actual cash expenditure; second, keeping debt capacity; moreover, no effects on corporate control. However, some limits are exposed, such as time limitation, retained profits need a long time to accumulate, besides, retained profits financing need to balance with dividend policy.

\subsubsection{Depreciation Financing}

Depreciation financing of fixed assets financing is a method that use the difference caused by opportunity cost and depreciation. And depreciation tax can bring internal capital to some extent, decreasing the pressure of SMEs, promoting the development of enterprises.

\subsection{External Financing}

External financing namely enterprises raise funds from other independent economical entities, including direct financing and indirect financing. Direct financing mainly involve bond financing, stock financing and public funds. Indirect financing contains bank loads and the funds from non-bank institutions. Compared with internal financing, external financing can raise funds in time, but with high cost.

\subsubsection{Direct Financing}

\section{1) Bond financing}

Bond financing required enterprises to issue bond to investors according to certain rules, pay certain interest within certain period of time, and repay principal according to agreed conditions. Bond financing is relatively flexible, interest and principal repayment can be formulated according to each corporate. However, in China, according to Securities Law of the People's Republic of China, some conditions are required to meet to issue bonds, namely, corporations' net assets should be not less than 30 million Yuan, and net assets of a limited liability company should be more than 60 million Yuan, in addition to the average distributable profits in the last three years is enough to pay a year interest of corporate bonds.

\section{2) Equity financing}

Equity financing means enterprises shareholder give up part of ownership and introduce new shareholders by increasing capital of enterprises. This shows an advantage that enterprises don't need to pay interest, but new shareholders can share enterprises' profits with old enterprises.

\section{3) Public funds}

Public funds mainly include commercial credit and private lending. Commercial credit means enterprises provide credit with direct relation to commodity transaction each other, such as payment by installment or credit, and down payment, which can avoid lot of limits like bank loans and decrease the cost of raise funds. Private lending is that the lending occurs between the citizens, citizens and legal persons, and, citizens and other organizations, and is increasingly active with the advancement of the market economy of the society.

\subsubsection{Indirect Financing}

\section{1) Bank financing}

Bank financing is a method that enterprises take banks as an intermediary to raise funds. It is the usually method for corporate to get capital, yet, bank loans has many limits, such as the scale of the corporate, credit degree. Besides, the quantity and time of loans have been strictly formulated.

\section{2) Non-bank institution financing}


Financing from Other institution except bank has many methods, mainly includes finance leasing and Pawn Loans. Finance leasing is a transfer of risks and rewards of ownership of the leased asset to the lessee, but not the actual ownership. And financial leasing has special advantages in solving the problem of corporate financing compared with other tools. Compared with bank loans, pawn loans need to pay a higher overall cost included the safekeeping fee, premium and pawn transaction costs. Therefore the cost of pawn loans is high and the scale is relatively small. But its operation process is simple, so that it can quickly and timely solve the funding needs of the enterprises.

\section{Current Financing Situation of China's SMEs}

The phenomenon of SME financing difficulty exists in many countries in the world, even in the developed countries with relatively sound financial system, but this phenomenon in China is particularly prominent [3]. According to the survey of SME Bureau in 2008, 85.6\% of SME lack of liquidity, and 23\% of the defunct and discontinued SMEs are closely related to the leakage of capital. Although some policies carried on by the government has gradually improved the situation of SME financing, the phenomenon of financing difficulty in SME is still serious because the Credit capital failed to help the most in need of assistance enterprises in difficulty and SMEs' anemic symptoms remained unchanged. In 2009, a survey report from Tianjin shows: the financing climate index in second quarter of enterprises is 88.6, 0.7 points lower than the previous quarter, the only one that rose in the last quarter but decrease in this quarter of the 8 enterprises climate indexes. In Sichuan province, corporate financing climate index in second quarter also edged down to 0.3 , reached 80.2 , and run down in the mild recession interval. In Shandong province, with the input of capital, large enterprises financing climate index was 118.6, 17.3 points higher than the last quarter. Yet, SMEs is relatively low, only 76.2 and upgraded 0.5, 42.4 points behind the large enterprises. In Liaoning province, corporate financing climate index is 76.4, still in recession, SME was only 67.7, down 9.7 points. In Heilongjiang province, corporate liquidity climate index of the whole province is 82.1, still remained to run in recession; corporate financing climate index was 74.4, remained unchanged. Wondrously, big gap existed between big enterprises and SMEs, liquidity and financing climate index in SMEs is respectively lower 74.3 and 79.0 than that in large enterprises. In Zhejiang province which is relatively developed and has major of SMEs, the SMEs financing climate index is 105.8, 17.7 lower than large enterprises, industries with high proportion of SMEs like wholesale and retail trade, information IT, social services, accommodation and catering, and transportation, respectively decreased 2.8, 3.1, 8.1, 1.4 and 9.2. In all, the situation of SMEs financing is in difficulty.

\section{The Causes of SMEs' Financing Difficulties from Its Source}

The phenomenon of SME financing difficulties is caused by many reasons, such as corporate itself problems, banks limits, and credit institutions. This paper focuses its financing sources namely financing method to analyze financing difficulties of SME.

\subsection{Indirect Financing as the Main External Sources Is in Difficulty}

\section{Negative Effects from the System of Commercial Banks and Difficulty of Bank Loans}

Due to China's commercial banking system, especially the major big four state-owned commercial banks are experiencing a transition period and far from being truly market-oriented and commercialized [4]. In order to guard against financial risks, state-owned commercial banks actually have transformed their development strategy to large enterprises and cities in recent years. These changes caused SMEs located in the small cities have difficulties in getting access to credit service. In addition, it's still difficult for SME to get bank loans in terms of bank loans structural, effectiveness and sustainability. On the supply structure, mortgage guarantee as the primary condition of loans approval hinders the loans, besides, bank credit continue to prefer large enterprise or SMEs that run well, moreover, long-term loans are extremely low. This unbalanced structure has hindered the sustainability of SMEs with no doubt, consequently, lead to inefficient lending, lack credit monitoring and evaluation system in SMEs. In terms of the current situation of financial institutions matched with SMES, small and medium-sized financial institutions are small quantities, and face many problems and difficulties in its further development, thus are not able to satisfy the SMEs. More importantly, it’s difficult for SMEs to obtain guarantees as the weak financing credit, no qualitative or mortgage assets acceptable by banks, and no third-party en- 
terprises with enough credit rating to offer guarantees, making it possible to raise funds from banks. Therefore, banks and other financial institutions still have great limits for SMEs to raise funds.

\subsection{Direct Financing as the New External Sources Has Been Hindered}

Direct financing mainly includes bond financing, stock financing and public funds. With the gradual improvement of economy market, direct financing has been a new method to raise funds.

\subsubsection{The Marginalization of Bond and Stock Financing}

The capital market as an emerging and immature stock market in China only includes shanghai stock exchange and Shenzhen stock exchange, SME board market, and GEM, but no small enterprises regional markets. Thus these can be hard to meet the demand of SMEs for its further development, making it difficult to raise funds relying on capital market [5]. According to related statistics, in 2012, SME board listed 683 companies, the first financing amounted to 468.3 billion Yuan, the additional financing 127.7 billion Yuan, share allotment financing 2.6 billion Yuan. And the total financing nearly amounted to 600 billion, with the average financing of each enterprise reaching 900 million Yuan. Yet a large company listed in 2007 raised funds as high as 66.8 billion Yuan, equivalent to 70 SMEs. In terms of short-term bond financing, in 2008, Chinese banking market trader association accepted 6 SMEs registration as the allowance of issuing short-term bonds, pilot of SMEs short-term bond financing officially launched, and the first issue totaled 160 million Yuan, only a fraction of the total amount of short-term financing bonds in 2008 namely 138.46 billion Yuan. What else, the entry of capital market is difficult for SMEs because of the limitation of scale, cost and other conditions, such as corporations' net assets should be not less than 30 million Yuan, and net assets of a limited liability company should be more than 60 million Yuan, in addition to the average distributable profits in the last three years is enough to pay a year interest of corporate bonds. All of these have prevented the success financing from capital market, thus hindering the development of SMEs.

\subsubsection{Credit Guarantee Institutions Are Small-Scale}

The current development of credit guarantee industry which specially served for SMEs is difficult to meet the needs of improving the capacity of the credit for SMEs. The credit guarantee institutions built by government usually can only get a one-off financial support at the beginning of the preparation and lack of follow-up compensation mechanism. As for the credit guarantee institutions owned privately, they are limited by the system of ownership and have to bear the risk of loans guaranteed alone. They are unable to form sharing and collaboration mechanism with bank. Raising money from the credit guarantee institutions is the most effective tool of financing SMEs.

\subsubsection{Public Funds Need to Take Full Use of and Develop Normatively}

With the development of economy market, public funds increased rapidly. Yet, private finance has not been recognized by the government, existed as an illegal form. In fact, as the increasing financing demand of SMEs, public funds become more and more important to solve the leakage of funds in SMEs as the little supply of funds of formal channels. Still, SMEs has not taken full use of public funds, according to the date of 2011, SMEs inflow of public funds is between 500 - 600 billion Yuan, accounted for $30 \%$ of the total public funds. Besides, public funds lack standardization and legalization, in recent years, scams in public funds financing occurred increasingly, hitting the financing from public funds. Therefore, to promote the stable development of economy in China, the government should not guide the development of non-public economy, but also encourage and guide public investment.

\section{Conclusion}

SMEs have become the important force of sustained, rapid and healthy development of China's economy. There are many kinds of financing sources that can be adopted for financing small and medium-sized enterprises. It is important for SMEs to choose correct and appropriate financing sources to solve the company's financial difficulties. This paper mainly analyzes the causes of financial difficulties from its sources, find that less bank loans, issue problems of bond and stock, and that lack of standardization in public funds have hindered the successful financing of SMEs, offering help for other scholar to put forward solutions of financial difficulty in SMEs, such 
as decreasing the limits of bank loans and reinforcing the standard of public fund market. Through improvement of the financing sources, SMEs will become increasingly important and irreplaceable in promoting economic development in China.

\section{References}

[1] Beckand, T. and Demirguc-Kunt, A. (2006) Small and Medium Size Enterprises: Access to Finance as a Growth Constraint. Journal of Banking and Finance, 30, 2931-2943. http://dx.doi.org/10.1016/j.jbankfin.2006.05.009

[2] Berger A.N. and Udell, G.F. (2006) A More Complete Conceptual Framework for SME Finance. Journal of Banking and Finance. 30, 2945-2966.

[3] Lv, H.J. (2013) SME Financing Difficulties and Countermeasures. Central China Normal University, Wuhan.

[4] Li, Q.L. (2013) Innovation—Research on Financing Mode of SME—Exploration of the Financing Platform for SME. Zhejiang University, Hangzhou.

[5] He F.F. (2012) SME External Financing Difficulties and Solutions. Corporation Research, 251-252. 
Scientific Research Publishing (SCIRP) is one of the largest Open Access journal publishers. It is currently publishing more than 200 open access, online, peer-reviewed journals covering a wide range of academic disciplines. SCIRP serves the worldwide academic communities and contributes to the progress and application of science with its publication.

Other selected journals from SCIRP are listed as below. Submit your manuscript to us via either submit@scirp.org or Online Submission Portal.
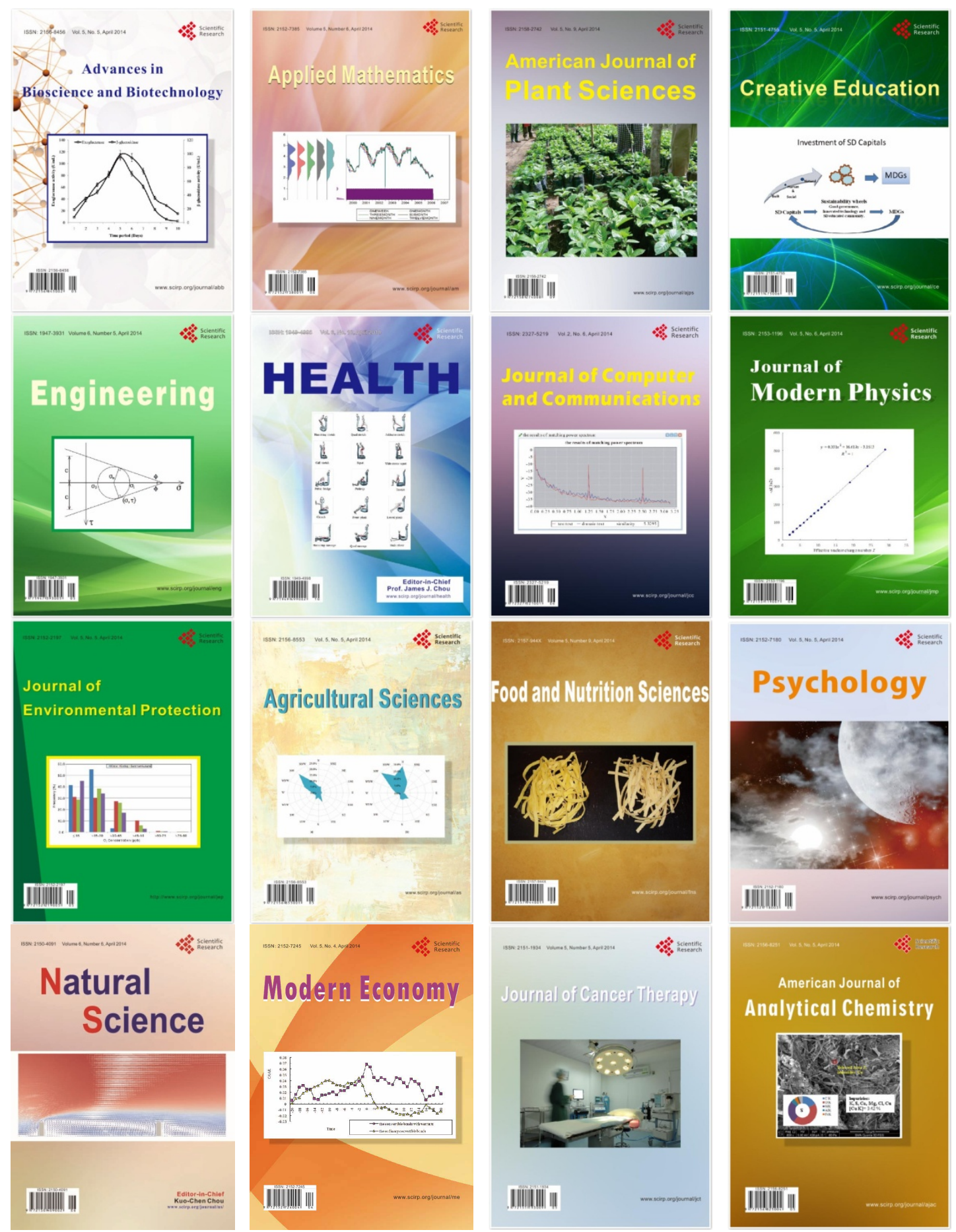